\title{
THE IMPACT OF CONTINUOUS TRAINING IN SMALL AND MEDIUM ENTERPRISES: LESSONS FROM AN INDUSTRIAL CASE ANALYSIS
}

\author{
Guillermo O. PÉREZ-BUSTAMANTE ILANDER ${ }^{1}$, Carla S. E. MARQUES ${ }^{2}$, \\ Marjan S. JALALI ${ }^{3}$, Fernando A. F. FERREIRA ${ }^{4}$ \\ ${ }^{1}$ Faculty of Economics and Business, University of Oviedo, \\ Avda. Del Cristo s/n, 33007 Oviedo, Spain \\ ${ }^{2}$ Department of Economics, Sociology and Management, \\ University of Trás-os-Montes e Alto Douro, Quinta dos Prados, \\ Apartado 2013, 5001-801 Vila Real, Portugal \\ ${ }^{3}$ ISCTE Business School, BRU-IUL, University Institute of Lisbon, \\ Avenida das Forças Armadas, 1649-026 Lisbon, Portugal \\ ${ }^{4}$ ISCTE Business School, BRU-IUL, University Institute of Lisbon, Avenida das Forças \\ Armadas, 1649-026 Lisbon, Portugal \& Fogelman College of Business and Economics, \\ University of Memphis, Memphis, TN 38152-3120, USA \\ E-mails: ${ }^{1}$ gperez@uniovi.es; ${ }^{2}$ smarques@utad.pt; ${ }^{3}$ marjan.jalali@iscte.pt; \\ ${ }^{4}$ fernando.alberto.ferreira@iscte.pt,fernando.ferreira@memphis.edu (corresponding author) \\ Received 01 September 2013; accepted 22 June 2014
}

\begin{abstract}
In the current competitive environment, great emphasis is placed on the knowledge and skills of the workforce as important elements in achieving organizational goals. As this focus on employee skills has increased, so have organizational programs and initiatives to ensure that the training in place to develop those skills is not sporadic, but rather part of a continuous effort toward keeping employee skills up to date. It becomes fundamental, in this context, to understand such programs and evaluate their impact, both within companies and externally, in terms of their decision making and business results. This paper aims to do that, through a study of the work-related training practices of industrial firms in the Northern-Spanish region of Asturias. In addition, it develops a new variable - training intensity - and examines its impact on the planning, execution and evaluation of training programs in these firms. Among other findings, our study confirms that training-intensive firms have a more defined strategic approach to the market and are generally more conscious of business competition than their non-training-intensive competitors. Implications for management are also presented.
\end{abstract}

Keywords: competitiveness, industrial sector, continuous training, training investment and evaluation, specific and generic training, case analysis.

JEL Classification: J24, J31, L11, O31, O47. 


\section{Introduction}

As the pace of business competition increases, firms are ever more required to be dynamic and innovative; which, in turn, demands that these qualities be manifest in their workforce (cf. Grant 1991; Streb et al. 2008; García-Morales et al. 2012; Hunter et al. 2012). A firm may adopt new productive systems based on the latest technological and organizational patterns to meet or stay ahead of its competitors; but such investments are likely to bear little fruit unless they are introduced in the context of a support structure of highly-qualified technical staff (cf. Blundell et al. 1999; Chi et al. 2008; Othman et al. 2012; Santos-Vijande et al. 2012).

In addition to increasing competition, authors such as Garofano and Salas (2005), Iatagan et al. (2010) and Hammervoll (2012) point to other factors, which have also led to a greater attention to the workforce and its training. These include the development of a knowledge intensive economy, globalization, the speed of technological change, increased educational levels in the working population, and the influence of AngloAmerican business perspectives. Such factors have produced greater pressure for training in general, and evidenced the need for a model of continuous training (Luo 2007) in particular. From the firm's standpoint, this model requires that work-related training not be an afterthought, but rather form part of a predefined and planned effort to continuously facilitate employee learning, and so improve productivity and work performance (see Noe 2008; Hammervoll 2012; Othman et al. 2012; Neirotti, Paolucci 2013).

In this paper, we analyze the continuous training practices of industrial small and medium enterprises (SMEs) in the region of Asturias, in Northern Spain. On the basis of the firms' reports, we are interested in identifying the type of training preferentially provided, how it is delivered, and its effects on human resource practices. We furthermore create a new variable - training intensity - and analyze the extent to which it produces significant differences in the provision of training, its execution, evaluation, and impact on performance. In spite of the remarkable progress achieved over the years, it is widely agreed that the discussion on training has not been put to rest. Therefore, there is considerable scope to report the results of continuous training in industrial SMEs with the objectives (and context) presented in this study.

The remainder of the paper is structured as follows. The next section presents a review of relevant literature on both the theoretical framework of training and its possible effects on business profitability and wage increases. The following section describes the context of the Spanish training system and presents the sample. The methodological aspects and the results of the continuing training approaches of Asturian industrial firms are presented in the ensuing section. This section also analyzes the impact of training intensity on competitive variables and presents some of the lessons learned. The final section concludes the paper, providing recommendations for decision makers in terms of continuous training management in industrial firms. 


\section{Brief review of the literature}

In the current information based-society, the production of knowledge has risen as the main source of competitive advantage (cf. Lara 2011). For this to take place, it is essential that innovative research and development (R\&D) investments be undertaken and a knowledgeable workforce be trained. Human Resource Management (HRM) thus acquires a strategic dimension; and new competencies are called for to give answer to the challenges of a volatile environment (Mulholland et al. 2005; Streb et at. 2008; Nair, Vohra 2010; Finch et al. 2012; García-Morales et al. 2012; Hunter et al. 2012). In this context, innovation and dynamic adaptation to change are the only way to prevent competitors from eroding a firm's competitive edge; and such adaptation requires not only the ability, but the willingness of employees to engage in it.

Indeed, human resources (HR) in general, and efforts toward their continuous training in particular, are increasingly seen as fundamental elements to achieving a sustained competitive advantage, which has led to the "interaction and convergence of strategy and HRM issues" (Barney et al. 2001: 627). Thus, rather than being considered in isolation, training is developed in concord with other HR policies, from recruitment to reward management and career planning; and in addition, all these elements are considered strategically, i.e., in terms of their potential contribution to business performance and goals (Purcell 1999; Akhtar et al. 2008).

Achieving business goals and a sustained competitive advantage, one which "continues to exist after efforts to duplicate that advantage have ceased" (Barney 1991: 102), requires that the resources and capabilities underlying that advantage be valuable, rare, costly to imitate, and that the firm be organized to fully exploit them (Barney, Hesterley 2012). While "individual HRM practices may be imitable [...] HRM systems and routines, which develop over time, may be unique to a particular firm and contribute to the creation of specific human capital skills" (Barney et al. 2001: 627).

Furthermore, the intangibility of the human element, in what refers to characteristics such as "knowledge, skills and attitudes [...] and organizational knowledge" adds an additional layer of inimitability (Aragón et al. 2003: 956). While developing HR requires a multi-pronged approach, and indeed the integration of various HR practices, the fundamental role of training is increasingly recognized, as "the main activity in order to have qualified, flexible and well-prepared employees [...] and to achieve the correct running of each stage of the process of knowledge management [...]" (Aragón et al. 2003: 956).

Firms at the technological frontier must use routine-based innovation knowledge; and to do so, need to build a "stock" of knowledge, from both internal expertise and high-tech knowledge (Chou, Zolkiewski 2012). Likewise, with workers, their accumulated stock of Human Capital at a given time provides them with both the incentives and opportunities for further investments in Human Capital formation, highlighting the self-sustaining nature of individual capital growth (Foss 1997; Blundell et al. 1999; Tracey 2012).

In broad terms, Human Capital is composed of three elements: (1) early ability; (2) qualifications and knowledge acquired through formal schooling and post-school qualifica- 
tions; and (3) competences and expertise acquired through training while at work (i.e. continuous training) (cf. Blundell et al. 1999; Mulholland et al. 2005). Training can thus be defined as those courses undertaken post schooling, which are designed to help individuals develop skills and use them in their jobs (Blundell et al. 1999). We understand that continuous training is related to the provision of job related knowledge and skills which help make individuals flexible and able to adapt to change and innovation (Noe 2008).

As an investment, training should only be undertaken if its expected return is greater than the market rate of interest (for further discussion, see Veum 1995; Blundell et al. 1999; Görlitz 2011). Traditional Human Capital models distinguish between general training, which is highly transposable between firms; and specific training, which results in productivity increases in only one firm (Becker 1964). The central element in these models relates to the ability to appropriate the returns of the training effort, such that general training should be financed by employees; whereas specific training should be financed by the firm itself; or at most be co-financed, in order to reduce the possibility of opportunistic behaviors by the trained workers.

The extent to which the knowledge transferred can be turned into Human Capital, however, depends on the extent to which employees devote effort to learning, and effectively apply new skills. From a strategic standpoint, then, the workforce can be an important source of competitive advantage (Hatch, Dyer 2004). Knowledgeable and specialized employees add value are scarce, difficult to replicate and cannot be easily substituted. Nevertheless, competitive value is neither an intrinsic property of resources, nor is it static; value is accrued with time, with investments toward increasing and improving those resources, and it is also dependent on the nature of the industry in question (Collis, Montgomery 1995). In the industrial sector, for instance, efforts to increase the competitive value of human resources have tended to focus on a more narrow form of training, where the objective is to teach workers how to fully exploit a machine, by knowing all the technical aspects related to it and the job in question. The next section characterizes the Asturias region, from which the sample of industrial firms in this study was obtained.

\section{The case of the Asturias region: context and sample}

Public support for work-related training in Spain is subsidized by the Fundación Tripartita para la Formación en el Empleo (i.e. Tripartite Foundation for Training and Employment, after translation; Tripartite Foundation from now on). This Foundation was created in 1980 by the Spanish Administration, trade unions and companies' associations. A $0.7 \%$ levy on monthly wages $(0.6 \%$ paid by companies and $0.1 \%$ by workers) was set to finance workers' skills acquisition and requalification. The Foundation's budget is financed by the levy and money from the Spanish Government, though firms are able to recover their training levy contributions, with the amount of their financial support for training plans depending on the size of the firm.

In the Asturias region, the data from the observatory for continuous training of the Tripartite Foundation shows that, in 2012, 6.30\% of the firms (1.993 out of 31.633 firms) 
performed training for 32.324 individuals out of a total of 295.312 individuals employed in the region (10.95\%). These firms invested $4.190 .000 €$ in training, out of an initial available budget from the levies of $6.450 .000 €$ ( $64.96 \%$ use rate). In the industrial sector, 484 firms $(24.29 \%)$ performed training, using $2.300 .000 €$ from an initial credit of $3.380 .000 €(68.04 \%$ use rate). The backdrop for these numbers is a national labor market with high levels of unemployment and a growing casualization of the labor force, with temporary labor contracts representing $31.90 \%$ of all work contracts. The industrial relations system in Spain has been defined as one of weak and fragmented corporatism, despite the existence of legally enforceable sectorial bargaining.

Given this context, our focus is on the region of the Asturias, and industrial SMEs within it in particular. The choice of the industrial sector is of interest, because it allows us to analyze continuous training in the context of a very traditional economic sector, where the stereotype is still very much of a Fordist and largely mechanistic approach, with narrow training. The focus on SMEs - firms with 30-250 employees - has to do with the structure of the Asturian industrial sector, of which SMEs are highly representative. The sample population was drawn from the Bureau Van Dijk: SABI - Sistema de Análisis de Balances Españoles - data base. This provides accounting and financial information published up to 6 months after the fiscal year in analysis. The initial number of industrial firms retrieved from the data base was of 497. Of these, 109 were did not belong to the industrial sector, were closing down or could not be contacted. A postal survey was sent to the remaining 388.115 of these returned usable surveys, representing a response rate of $29.63 \%$ (see Table 1 ), which is a fairly good response rate in the Social Sciences (M. Hill, A. Hill 2005).

Table 1. Sample size and response rates

\begin{tabular}{|c|c|}
\hline Population & Industrial firms of Asturias employing between 30 and 250 workers \\
\hline Geographic area & Principado de Asturias (Spain) \\
\hline Data collection method & Postal survey \\
\hline Sample unit & HRM Managers \\
\hline Population $(n)$ & 388 \\
\hline Sample size $(t)$ & 115 \\
\hline Response rate & $29.63 \%$ \\
\hline Sample error $(k)$ & $7.7 \leq \%$ \\
\hline Confidence level & $\mathrm{P}=\mathrm{q}=0.5$ \\
\hline
\end{tabular}

\section{Methodology and results}

As noted above, a survey methodology was adopted. The questionnaire was developed and tested through personal interviews with HRM managers of different companies that provide training in order to check both its accuracy and a correct understanding of the questions. After small adjustments, it was applied through the use of a postal survey sent 
to the target firms for data collection. The final questionnaire used was composed of closed questions, with answers measured on 5-point Likert scales, where higher values represented greater levels of relevance or importance attributed to an issue by the firm. Participant companies were asked regarding their training practices (i.e. type of training, where it takes place, funding, reasons for training and so on); as well as regarding the strategic importance attributed to such actions, as measured by the importance attached to them and the extent to which they were considered an investment, for instance.

Because this research was essentially exploratory, no specific hypotheses were developed. However, we were interested in the following key research questions:

1) To what extent was general vs. specific training carried out in these firms? Given the size of the firms in question and their industrial nature, there was an expectation that most of the training would be firm-specific, relating to particular acquired machinery or technology;

2) Who was supporting the cost of these training initiatives, was the cost distribution consistent with theory (i.e. supported by employees in the case of general training, and by firms for specific training)? More importantly, perhaps, given these general characteristics, we wanted to see if we could identify noteworthy differences between firms in their approach to training; and

3) Considering their level of training intensity, would this variable lead to significant differences in:

a) the execution of training programs, and the extent to which they were considered a strategic variable for the company;

b) the manner in which performance and training evaluation took place; and

c) the outcomes of training.

\subsection{General characteristics of the sample and firms' training practices}

There was a noteworthy prevalence of training among the firms in our sample. Of the 115 firms who answered the questionnaire, 109 (94.78\%) had implemented training sometime in the past decade. However, this was not universally reflected among employees: of the 9.386 employees encompassed by the study, only around a third (3.605) had benefitted from training.

As noted above, we were also interested to see whether the financing of the training programs provided was aligned with Human Capital theory. In broad terms, this was found to be the case. General training was mostly provided off the job and at the expense of workers' time, whereas the costs of specific training tended to be covered by the firms, by being performed on the job and during working time. In the case of general training, firms subsequently tried to limit potential resulting labor mobility through efficiency wages and by linking promotions to Human Capital.

Despite this overall alignment with the theory, it is worth noting that of the firms in the sample providing specific training, 39 did so off the job, outside of work hours, and with external trainers - characteristics typically associated with general training. This is surprising because it shows job specific training being provided at employees' expense, where theory would predict the opposite. 


\subsection{Intensity of training}

In order to analyze the research questions related to training intensity and its impact, the firms in the sample were classified according to five items, designed to measure this variable (intensity of their continuous training practices): (1) the number of reasons indicated for providing training; (2) the number of categories of workers being trained; (3) the number of different training contents provided; (4) the intensity of the evaluation process; and (5) the self-reported strategic importance of the workforce qualification process. The intensity of training index (IT) was built according to formulation (1), which multiplies each method declared by the company (i.e. attendance $\left(X_{1}\right)$, satisfaction $\left(X_{2}\right)$, acquisition of knowledge $\left(X_{3}\right)$, application of said knowledge to job tasks $\left(X_{4}\right)$ and company analysis of business results $\left.\left(X_{5}\right)\right)$ by an increasing additional number $i \in\{1,5\}$ :

$$
I T=\sum_{i=1}^{5} X_{i} . i \text {. }
$$

The variables were standardized for the analysis. In order to classify the firms into groups, a $K$ means cluster analysis was performed. Distances were computed using Euclidean distance, and the "classify and iterate" method was used, forcing the program to select two clusters within a maximum of 10 iterations. The data was treated with IBM's SPSS statistical package, and the cluster analysis identified two groups: (1) a training-intensive group, formed by 53 of the firms in the sample; and (2) a group of non-training-intensive firms, which was composed of 55 firms (one firm was not classified in either group). Table 2 presents the scores of the two groups for each of the items which make up the intensity of training variable.

Table 2. Final conglomerate centroids (standardized variables)

\begin{tabular}{lcc}
\hline & \multicolumn{2}{c}{ Conglomerate } \\
\hline Workforce qualifications & 1 & 2 \\
\hline Number of trained worker categories & .39645 & -.43465 \\
\hline Number of training course categories & .53874 & -.31628 \\
\hline Number of origins for training proposals & .75132 & -.53239 \\
\hline Intensity of evaluation & .53410 & -.32467 \\
\hline
\end{tabular}

Table 3 presents the results of the confirmatory discriminant analysis of these clusters. This coherently classified $94.78 \%$ of the firms, with a Spearman coefficient of 0.946 , statistically significant at a $99 \%$ level.

In terms of general firm characteristics, the data showed that those in the high training intensity group had been in the market longer, had older employees and managers, experienced less staff turnover and had a more specialized workforce than non-trainingintensive firms. Although these differences did not reach significance, the pattern was consistent throughout.

A series of $T$ tests and ANOVAs were then run to investigate the differences between the groups on a number of variables. The results are presented in Tables 4 to 8 . 
Table 3. Results of the contingency table of the discriminant analysis

\begin{tabular}{|c|c|c|c|c|c|}
\hline & & & \multicolumn{2}{|c|}{ Initial number of cases } & \multirow[t]{2}{*}{ Total } \\
\hline & & & $\begin{array}{l}\text { Training- } \\
\text { intensive }\end{array}$ & $\begin{array}{l}\text { Non-training- } \\
\text { intensive }\end{array}$ & \\
\hline \multirow[t]{6}{*}{$\begin{array}{l}\text { Group predicted } \\
\text { for analysis } 1\end{array}$} & $\begin{array}{l}\text { Training- } \\
\text { intensive }\end{array}$ & Observed & 50 & 0 & 50 \\
\hline & & $\begin{array}{c}\% \text { of the group } \\
\text { predicted for analysis } 1\end{array}$ & $100 \%$ & $0 \%$ & $100 \%$ \\
\hline & & Resid. corrected & 9.8 & -9.8 & \\
\hline & $\begin{array}{l}\text { Non-training- } \\
\text { intensive }\end{array}$ & Observed & 3 & 55 & 58 \\
\hline & & $\begin{array}{c}\% \text { of the group } \\
\text { predicted for analysis } 1\end{array}$ & $5.2 \%$ & $94.8 \%$ & $100 \%$ \\
\hline & & Resid. corrected & -9.8 & 9.8 & \\
\hline \multicolumn{2}{|c|}{ Total } & Observed & 53 & 55 & 108 \\
\hline \multicolumn{3}{|c|}{$\%$ of the group predicted for analysis 1} & $49.1 \%$ & $50.9 \%$ & $100 \%$ \\
\hline
\end{tabular}

Table 4. Strategic consideration of continuing training

\begin{tabular}{lccr}
\hline \multicolumn{1}{c}{ Managers' responses } & $\begin{array}{c}\text { Training- } \\
\text { intensive }\end{array}$ & $\begin{array}{c}\text { Non-training- } \\
\text { intensive }\end{array}$ & Total \\
\hline Training costs are considered investments $t=0.005$ & $4.21^{*}$ & $3.58^{*}$ & 3.90 \\
\hline Training is performed only when needed & 3.62 & 3.29 & 3.46 \\
\hline Training aims to solve long term needs & 3.26 & 2.96 & 3.11 \\
\hline Employees take part in the planning of training & 2.79 & 2.55 & 2.67 \\
\hline Workforce productivity is considered strategic $t=0.011$ & $4.49^{*}$ & $4.09^{*}$ & 4.29 \\
\hline Workforce qualification is considered strategic $t=0.000$ & $4.45^{* *}$ & $3.78^{* *}$ & 4.11 \\
\hline
\end{tabular}

Notes: Responses on 5 -point Likert scales $(1=$ minimum and $5=$ maximum $) .{ }^{*}$ Significant at a $0.99 \%$ level. *Significant at a $0.95 \%$ level.

As shown in Table 4, there were significant differences between the two groups in the extent to which training was a strategic consideration. Training-intensive firms placed greater value on training programs as an investment $\left(M_{\text {intensive }}=4.21\right.$ vs. $\left.M_{\text {non-intensive }}=3.58 ; t=0.005\right)$; and were more likely to consider worker qualifications $\left(M_{\text {intensive }}=4.45 \mathrm{vs.} M_{\text {non-intensive }}=3.78 ; t=0.000\right)$ and productivity $\left(M_{\text {intensive }}=4.49\right.$ vs. $\left.M_{\text {non-intensive }}=4.09 ; t=0.011\right)$ as strategic resources than their non-training-intensive counterparts. Training-intensive firms also revealed more commitment to HRM practices in general than their non-training-intensive counterparts (see Table 5). 
Table 5. Commitment to HRM practices

\begin{tabular}{lccc}
\hline \multicolumn{1}{c}{$\%$ of firms and managers responses } & $\begin{array}{c}\text { Training- } \\
\text { intensive }\end{array}$ & $\begin{array}{c}\text { Non-training- } \\
\text { intensive }\end{array}$ & Total \\
\hline Job analysis and description & 83 & 70.9 & 76.9 \\
\hline Performance appraisal $t=0.002$ & $83^{*}$ & $56.4^{*}$ & 69.4 \\
\hline Teamworking & 79.2 & 76.4 & 77.8 \\
\hline Training implemented & 100 & 100 & 100 \\
\hline Online training $t=0.004$ & $45.3 *$ & $20 *$ & 32.4 \\
\hline Efficiency wages (superior) & 41.5 & 36.4 & 38.9 \\
\hline Wages equal to the mean & 58.5 & 61.8 & 60.2 \\
\hline Wages lower than the mean & 0 & 1.8 & 0.9 \\
\hline Use of performance appraisal for promotion $t=0.006$ & $50^{*}$ & $19.4 *$ & 37.3 \\
\hline Internal training used for promotion $t=0.010$ & $66^{*}$ & $41.8^{*}$ & 53.7 \\
\hline De-centralized decision making processes $(1)$ & 2.40 & 2.26 & 2.33 \\
\hline Specialized workforce (1) & 3.38 & 3.18 & 3.218 \\
\hline
\end{tabular}

Notes: (1) Responses on 5 -point Likert scales $(1=$ minimum and $5=$ maximum $)$ ** Significant at a $0.99 \%$ level. * Significant at a $0.95 \%$ level.

There were statistically significant differences between the two groups in the implementation of performance appraisal $\left(M_{\text {intensive }}=83 \%\right.$ vs. $\left.M_{\text {non-intensive }}=56.4 \% ; t=0.002\right)$, online training $\left(M_{\text {intensive }}=45.3 \%\right.$ vs. $\left.M_{\text {non-intensive }}=20 \% ; t=0.004\right)$, the use of performance appraisal for promotion $\left(M_{\text {intensive }}=50 \%\right.$ vs. $\left.M_{\text {non-intensive }}=19.4 \% ; t=0.006\right)$ and the use of internal training $\left(M_{\text {intensive }}=66 \%\right.$ vs. $\left.M_{\text {non-intensive }}=41.8 \% ; t=0.010\right)$. Taken together, these results suggest that training-intensive firms have a more formalized and strategic approach toward their workforce management.

Table 6 highlights the differences between the two groups, in terms of the proposal of training, training topics, categories of employees, and the evaluation methods implemented. A larger percentage of training-intensive firms reported that their training programs originated within Middle Management $\left(M_{\text {intensive }}=84.9 \%\right.$ vs. $M_{\text {non-intensive }}=$ $51.5 \% ; t=0.001)$, other HR Managers $\left(M_{\text {intensive }}=56.6 \%\right.$ vs. $M_{\text {non-intensive }}=30.9 \%$; $t=0.006)$ and, to a lesser extent, from performance appraisal evaluation processes $\left(M_{\text {intensive }}=35.8 \%\right.$ vs. $\left.M_{\text {non-intensive }}=10.9 \% ; t=0.002\right)$. Training in these firms was also more likely to result from the perceived need to adapt technologically $\left(M_{\text {intensive }}=\right.$ $73.6 \%$ vs. $M_{\text {non-intensive }}=50.9 \% ; t=0.013$ ), and to be linked to their strategic business plans $\left(M_{\text {intensive }}=52.8 \%\right.$ vs. $\left.M_{\text {non-intensive }}=23.6 \% ; t=0.002\right)$.

As expected, training-intensive firms trained a greater percentage of their workforce than their non-training-intensive counterparts. This difference was significant for every worker category other than qualified manual staff $\left(M_{\text {intensive }}=94.3 \%\right.$ vs. $M_{\text {non-intensive }}=$ $85.5 \% ; t=0.127$ ), which is also the category which most participates in training programs for both groups. 
Table 6. Execution of continuous training

\begin{tabular}{|c|c|c|c|}
\hline$\%$ of firms & $\begin{array}{l}\text { Training- } \\
\text { intensive }\end{array}$ & $\begin{array}{l}\text { Non-training- } \\
\text { intensive }\end{array}$ & Total \\
\hline \multicolumn{4}{|l|}{ Source of training } \\
\hline Request of employees & 58.5 & 41.8 & 50 \\
\hline Request of middle managers $t=0.001$ & $84.9 *$ & 51.5 & 69.4 \\
\hline Subsidized training & 66 & 58.2 & 62 \\
\hline Performance appraisal results $t=0.002$ & $35.8^{*}$ & $10.9 *$ & 23.1 \\
\hline Future business plans $p=0.002$ & $52.8^{*}$ & $23.6^{*}$ & 38 \\
\hline Adapt to new technologies $t=0.013$ & $73.6^{*}$ & $50.9 *$ & 62 \\
\hline Request of HR managers $t=0.006$ & $56.6^{*}$ & $30.9 *$ & 43.5 \\
\hline Request of trade unions & 13.2 & 12.7 & 13 \\
\hline \multicolumn{4}{|l|}{ Content of training } \\
\hline Inductment $t=0.000$ & $54.7 * *$ & $21.8^{* *}$ & 38 \\
\hline Informatics $t=0.000$ & $92.5^{* *}$ & $47.3 * *$ & 69.4 \\
\hline Trainers training $t=0.041$ & $15.1 *$ & $3.6^{*}$ & 9.3 \\
\hline Labor and health prevention $t=0.030$ & $96.2^{*}$ & $83.6^{*}$ & 89.8 \\
\hline New product lines $t=0.004$ & $43.4^{*}$ & $18.2^{*}$ & 30.6 \\
\hline Maintenance $t=0.001$ & $52.8^{*}$ & $21.8^{*}$ & 37 \\
\hline New technologies, machines $t=0.000$ & $86.8 * *$ & $40 * *$ & 63 \\
\hline Language skills $t=0.001$ & $37.7 *$ & $10.9^{*}$ & 24.1 \\
\hline \multicolumn{4}{|l|}{ Categories of evaluations } \\
\hline Course attendance $t=0.003$ & $69.8^{*}$ & $41.8^{*}$ & 55.6 \\
\hline Employees' satisfaction $t=0.039$ & $64.2^{*}$ & $45.5^{*}$ & 54.6 \\
\hline Knowledge and skills acquired $t=0.004$ & $83 *$ & $58.2 *$ & 70.4 \\
\hline Implementation of knowledge and skills to the job $t=0.001$ & $88.7^{*}$ & $61.8^{* *}$ & 75 \\
\hline Improvement in business $t=0.000$ & $66^{* *}$ & $32.7^{*}$ & 49.1 \\
\hline \multicolumn{4}{|l|}{ Categories of workers } \\
\hline Upper level managers $t=0.025$ & $45.3 *$ & $25.5^{*}$ & 35.2 \\
\hline Middle managers $t=0.004$ & $83^{*}$ & $58.2^{*}$ & 70.4 \\
\hline University technicians $t=0.000$ & $69.8 * *$ & $36.4^{* *}$ & 52.8 \\
\hline Administrative and commercial staff $t=0.000$ & $79.2 * *$ & $45.5^{* *}$ & 62 \\
\hline Qualified manual workers & 94.3 & 85.5 & 89.8 \\
\hline Non-qualified manual workers & $71.7^{*}$ & $49.1 *$ & 60.6 \\
\hline
\end{tabular}

Notes: Responses on 5 -point Likert scales $(1=$ minimum and $5=$ maximum $)$. $* *$ Significant at a $0.99 \%$ level. *Significant at a $0.95 \%$ level. 
Regarding training execution, Table 7 shows that both groups preferentially sought out specific knowledge $\left(M_{\text {intensive }}=3.94\right.$ vs. $\left.M_{\text {non-intensive }}=3.65 ; t=0.152\right)$.

Table 7. Commitment to training

\begin{tabular}{|c|c|c|c|}
\hline \multicolumn{4}{|c|}{ Commitment to Training ( $\%$ of positive responses) } \\
\hline Training Objectives (1) & Yes & No & Total \\
\hline Training objective is to provide specific knowledge (1) & 3.94 & 3.65 & 3.81 \\
\hline \multicolumn{4}{|l|}{ Course length } \\
\hline Less of19 hours & 21.2 & 29.7 & 25.7 \\
\hline Between $20 \& 29$ hours & 12.1 & 24.3 & 18.6 \\
\hline Between $30 \& 39$ hours & 15.2 & 5.4 & 10 \\
\hline Between $40 \& 49$ hours & 9.1 & 10.8 & 10 \\
\hline Between $50 \& 59$ hours & 18.2 & 5.4 & 11.4 \\
\hline More than 60 hours & 24.2 & 24.3 & 24.3 \\
\hline \multicolumn{4}{|l|}{ Place of training } \\
\hline None on the job $t=0.001^{*}$ & $18.9 *$ & $50 *$ & 34.6 \\
\hline Up to $50 \%$ on the job $p=0.001^{*}$ & $58.6^{*}$ & $24.1 *$ & 41.1 \\
\hline More than $50 \%$ on the job & 17 & 16.7 & 16.8 \\
\hline All on the job & 5.7 & 9.3 & 7.5 \\
\hline \multicolumn{4}{|l|}{ Time table of training } \\
\hline None during working time rtcH $(-2.1)$ & $7.5^{\tau}$ & $22.2^{\tau}$ & 15 \\
\hline Up to $50 \%$ during working time & 47.2 & 35.2 & 41.1 \\
\hline More than $50 \%$ during working time & 20.8 & 16.7 & 18.7 \\
\hline All during the working time & 24.5 & 25.9 & 25.2 \\
\hline \multicolumn{4}{|l|}{ Trainers who are workers } \\
\hline None $t=0.035$ & $37.7 *$ & $63.6^{*}$ & 50.9 \\
\hline Up to $50 \%$ & 49.1 & 30.9 & 39.8 \\
\hline More than $50 \%$ & 9.4 & 1.8 & 5.6 \\
\hline All & 3.8 & 3.6 & 3.7 \\
\hline \multicolumn{4}{|l|}{ Percentage of workers trained } \\
\hline Less than $10 \%$ & 22.6 & 39.2 & 30.8 \\
\hline Between $11 \& 29 \%$ & 24.5 & 15.7 & 20.2 \\
\hline Between 30 \& 49\% & 17 & 15.7 & 16.3 \\
\hline Between $50 \& 74 \% t=0.042$ & $22.6^{*}$ & $5.9^{*}$ & 14.4 \\
\hline Between $75 \%$ \& $100 \%$ & 13.2 & 23.5 & 18.3 \\
\hline Quick changes in the environment & 34.7 & 29.6 & 32 \\
\hline Mean duration of courses in hours & 64.12 & 72.03 & 68.3 \\
\hline Percentage of workers trained & 38.51 & 36.69 & 37.61 \\
\hline
\end{tabular}

Notes: (1) Responses on 5 -point Likert scales $(1=$ minimum and $5=$ maximum $) . *$ Significant at a $0.95 \%$ level; ${ }^{\tau}$ Standardized Habermans residuals. 
A larger percentage of non-training-intensive firms resorted solely to external trainers for the development of their training efforts $\left(M_{\text {non-intensive }}=63.6 \%\right.$ vs. $M_{\text {intensive }}=$ $37.7 \% ; t=0.035)$ and performed their programs off the job $\left(M_{n o n-i n t e n s i v e}=50 \%\right.$ vs. $\left.M_{\text {intensive }}=18.9 \% ; t=0.001\right)$, while a larger percentage of training-intensive firms ran up to $50 \%$ of their programs on firm premises $\left(M_{\text {intensive }}=58.6 \%\right.$ vs. $M_{\text {non-intensive }}=$ $24.1 \% ; t=0.001)$.

\subsection{Impact of training intensity on business results}

In general, training-intensive firms appeared more conscious of business competition than their non-intensive counterparts. However, there were no significant differences in the levels of importance attributed to the need for innovation, or workforce autonomy, participation and openness between the two groups. This might be explained by the increasing turbulence of the external environment, and firms' need to adapt to it, whether they are training intensive or not (Table 8).

Table 8 . Valuation of competitive variables according to training intensity

\begin{tabular}{|c|c|c|}
\hline & $\begin{array}{l}\text { Training-intensive } \\
\text { firms }\end{array}$ & $\begin{array}{l}\text { Non-training-intensive } \\
\text { firms }\end{array}$ \\
\hline Labor productivity $t=0.011$ & $4.49 *$ & $4.09^{*}$ \\
\hline Workforce qualification $t=0.000$ & $4.45^{*}$ & $3.78^{*}$ \\
\hline Efficiency $t=0.030$ & $4.52 *$ & $4.24 *$ \\
\hline Productivity & 4.40 & 4.35 \\
\hline Rentability & 4.38 & 4.19 \\
\hline Team working $t=0.048$ & $4.12 *$ & $3.81 *$ \\
\hline Cohesion "we are a family" $t=0.029$ & $3.56^{*}$ & $3.11 *$ \\
\hline Human relations $t=0.001$ & $4.06^{*}$ & $3.54 *$ \\
\hline Growth expansion $t=0.030$ & $3.83^{*}$ & $3.44 *$ \\
\hline Excellence and quality of results $t=0.003$ & $4.46^{*}$ & $4.04 *$ \\
\hline Innovation and change & 3.56 & 3.36 \\
\hline Workforce autonomy & 3.73 & 3.30 \\
\hline Workforce participation and openess & 3.58 & 3.17 \\
\hline Control & 3.92 & 3.58 \\
\hline Flexibility to adapt to changes & 4.14 & 3.85 \\
\hline Ideas from workforce $t=0.014$ & $3.73^{*}$ & $3.30^{*}$ \\
\hline Creative problem solving capabilities $t=0.023$ & $3.58^{*}$ & $3.17 *$ \\
\hline
\end{tabular}

Notes: Responses on 5 -point Likert scales $(1=$ minimum and $5=$ maximum $) .{ }^{*}$ Significant at a $0.95 \%$ level. 
Although it is widely acknowledged that training produces a variety of benefits, such as increased productivity and labor flexibility, quality improvements, product and process innovations, greater adaptability to market changes, and reduced absenteeism (cf. Rigby 2002; Santos-Vijande et al. 2012), Table 8 shows few significant differences in the impact of training intensity on business results. It is important to resist attaching too much importance to these numbers, however. Not only do they reach significance for pre-tax results, but training programs can produce other kinds of benefits for the organization, which may not be immediately apparent in economic indicators alone, such as greater commitment to the firm or higher levels of motivation.

\section{Conclusions}

Faced with an ever more volatile business environment, companies are increasingly turning to their HR as a potential source of sustainable competitive advantage. Within this trend, employee training has received particular attention, as a key way in which to fully exploit the potential of a company's HR in allowing it the dynamism, creativity and adaptability it need to survive in this new context (Aragón et al. 2003). It is no longer sufficient to simply provide employees with training, this training has to be strategic - linked to and integrated with other HR policies, and to the company's longterm goals and objectives in general. In this paper, we were interested to see to what extent such considerations were being held in a largely traditional setting, such as the industrial sector of Spanish Region of the Asturias.

Having revisited the theory of Human Capital and training, we found that as predicted by the theory, when the training provided was general (vs. specific), it was more likely to be paid for by the workers, under the assumption it would subsequently allow them to benefit from increased career opportunities and/or increased wages in the future. It is interesting to note, however, that most of the training within our sample was selfreported as specific, rather than general. Furthermore, in an apparently counter-intuitive manner, workers were found to be financing their specific training (by doing it off the job, and outside of work hours, for instance) as well as their general training. This is a relevant finding, and suggests that it is worth considering the increasing effects of changing labor market conditions on firms' training decisions. In particular, the results in this case are likely to have resulted from the inflexibility of the labor market; and to have been further compounded by the prevailing context of high unemployment.

This suggests an important area of intervention for policy makers, in terms of enabling greater labor market flexibility and trying curtail situations in which employers are able to acquire and take advantage of oligopsonistic positions. It should also concern managers, since previous research has shown that on-the-job training provided by in-house trainers produces better overall results in terms of creativity, productivity, quality, and profitability, among others (Aragón et al. 2003).

A further contribution of this study was the creation of a new variable - training intensity - and the assessment of its influence. The results showed a consistent and significant impact of training intensity. Training-intensive firms attached greater importance 
to worker qualifications and productivity as strategic resources, and displayed more commitment to HRM practices in general than their non-training-intensive counterparts. The training-intensive group also had training programs that were more aligned with strategic business plans, and a greater preoccupation with the need for technological adaptation. In terms of content and execution, intensive firms provided training in a greater number of diverse business topics, and were more likely to provide the training on the job and with recourse to internal trainers.

Again, these findings are of practical interest, and suggest that the measurement and development of training intensity should potentially be considered as an important objective for both policy makers and practitioners. Training programs in training intensive firms tend to be more strategic and are more likely to produce positive results - whether in terms of business performance or along more intangible variables, such as commitment, motivation, employee retention, creation of learning environments or even facilitate the assimilation of innovation within firms. As such, policy makers may want to consider this variable in attributing funding for training, and companies would do well to try to develop this intensity.

With respect to training evaluation, it is worth noting that for both groups, the percentage of firms using the most difficult to measure assessment of training (its business impact) was very close to the percentage of those using the easiest methods of training evaluation (course attendance or employee satisfaction). This is indicative of training courses and their desire to ensure they have measureable economic outcomes.

In terms of future research, longitudinal studies would be of interest, in order to address the lag between the provision of training and its production of results in the workplace. It would also be of interest to carry out similar and/or comparative analyses in different sectors and countries. In terms of practical recommendations for management practice, companies might want to consider the manner in which their specific or very specific training is provided, as it would likely be in their best interest to change to providing it to a greater extent internally, rather than through recourse to external trainers, as seems to currently be the case. Finally, the issue of informal training, and its provision and impact would also be a matter of great interest - in terms of both theory and practice.

\section{Acknowledgements}

A short version of this paper was presented at the $2^{\text {nd }}$ GIKA International Conference, held in Valencia, Spain. This study was funded by the European Social Fund and the Regional Ministry of Education and Science of the Principality of Asturias, Head Office of Vocational Training ("Consejería de Educación y Ciencia del Principado de Asturias, Dirección General de Formación”).

\section{References}

Akhtar, S.; Ding, D.; Ge, G. 2008. Strategic HRM practices and their impact on company performance in Chinese enterprises, Human Resource Management 47(1): 15-32.

http://dx.doi.org/10.1002/hrm.20195 
Aragón, A.; Barba, I.; Sanz, R. 2003. Effects of training on business results, International Journal of Human Resource Management 14(6): 956-980. http://dx.doi.org/10.1080/0958519032000106164

Barney, J. 1991. Firm resources and sustained competitive advantage, Journal of Management 17(1): 99-120. http://dx.doi.org/10.1177/014920639101700108

Barney, J.; Wright, M.; Ketchen Jr, D. 2001. The resource-based view of the firm: ten years after 1991, Journal of Management 27(6): 625-641. http://dx.doi.org/10.1177/014920630102700601

Barney, J; Hesterley, W. 2012. Strategic management and competitive advantage: concepts and cases. $4^{\text {th }}$ ed. New Jersey: Pearson.

Becker, G. 1964. Human capital: a theoretical and empirical analysis, with special reference to education. New York: National Bureau of Economic Research.

Blundell, R.; Dearden, L.; Costas, M.; Sianes, B. 1999. Human capital investment: the returns from education and training to the individual, the firm and the economy, Fiscal Studies 20(1): 1-23. http://dx.doi.org/10.1111/j.1475-5890.1999.tb00001.x

Chi, N.; Wu, C.; Lin, C. 2008. Does training facilitate SME's performance?, International Journal of Human Resource Management 19(10): 1962-1975. http://dx.doi.org/10.1080/09585190802324346

Chou, H.; Zolkiewski, J. 2012. Managing resource interaction as a means to cope with technological change, Journal of Business Research 65(2): 188-195.

http://dx.doi.org/10.1016/j.jbusres.2011.05.021

Collis, J.; Montgomery, C. 1995. Competing on resources: strategy in the 1990s, Harvard Business Review 73(4): 118-128.

Finch, J; Wagner, B.; Hynes, N. 2012. Resources prospectively: how actors mobilize resources in business settings, Journal of Business Research 65(2): 164-174.

http://dx.doi.org/10.1016/j.jbusres.2011.05.017

Foss, N. 1997. The classical theory of production and the capabilities view of the firm, Journal of Economic Studies 24(4/5): 307-324. http://dx.doi.org/10.1108/01443589710175825

García-Morales, V.; Jiménez-Barrionuevo, M.; Gutiérrez-Gutiérrez, L. 2012. Transformational leadership influence on organizational performance through organizational learning and innovation, Journal of Business Research 65(7): 1040-1050.

http://dx.doi.org/10.1016/j.jbusres.2011.03.005

Garofano, C.; Salas, E. 2005. What influences continuous employee development decisions?, Human Resource Management Review 15(4): 281-304. http://dx.doi.org/10.1016/j.hrmr.2005.10.002

Görlitz, K. 2011. Continuous training and wages: an empirical analysis using a comparison-group approach, Economics of Education Review 30(4): 691-701.

http://dx.doi.org/10.1016/j.econedurev.2011.02.008

Grant, R. 1991. The resource-based theory of competitive advantage: implications for strategy formulation, California Management Review 33(3): 114-165. http://dx.doi.org/10.2307/41166664 Hatch, N.; Dyer, J. 2004. Human capital as competitive advantage, Strategic Management Journal 25(12): 1155-1178. http://dx.doi.org/10.1002/smj.421

Hammervoll, T. 2012. Managing interaction for learning and value creation in exchange relationships, Journal of Business Research 65(2): 128-136.

http://dx.doi.org/10.1016/j.jbusres.2011.05.011

Hill, M; Hill, A. 2005. Investigação por questionário. Lisbon: Edições Sílabo.

Hunter, S.; Cushenbery, L.; Friedrich, T. 2012. Hiring an innovative workforce: a necessary yet uniquely challenging endeavor, Human Resource Management Review 22(4): 303-322.

http://dx.doi.org/10.1016/j.hrmr.2012.01.001

Iatagan, M.; Dinu, C.; Stoica, A. 2010. Continuous training of human resources: a solution to crisis going out, Procedia - Social and Behavioral Sciences 2(2): 5139-5146.

http://dx.doi.org/10.1016/j.sbspro.2010.03.835 
Lara, F. 2011. Knowledge society: opportunities and challenges, Management Decision 49(2): 297-302. http://dx.doi.org/10.1108/00251741111109179

Luo, X. 2007. Continuous learning: the Influence of national institutional logics and training attitudes, Organizations Science 18(2): 280-296. http://dx.doi.org/10.1287/orsc.1060.0230

Mulholland, P; Zdrahal, Z.; Domingue, J. 2005. Supporting continuous learning in a large organization: the role of group and organizational perspectives, Applied Ergonomics 36(2): 127-134. http://dx.doi.org/10.1016/j.apergo.2004.09.009

Nair, N.; Vohra, N. 2010. An exploration of factors predicting work alienation of knowledge workers, Management Decision 48(4): 600-615. http://dx.doi.org/10.1108/00251741011041373

Neirotti, P.; Paolucci, E. 2013. Why do firms train? Empirical evidence on the relationship between training and technological and organizational change, International Journal of Training and Development 17(2): 93-115. http://dx.doi.org/10.1111/ijtd.12003

Noe, R. 2008. Employee training and development. New York: Mc Graw Hill.

Othman, M.; Bhuiyan, N.; Gouw, G. 2012. Integrating workers' differences into workforce planning, Computers \& Industrial Engineering 63(4): 1096-1106.

http://dx.doi.org/10.1016/j.cie.2012.06.015

Purcell, J. 1999. Best practice and best fit: chimera or cul-de-sac?, Human Resource Management Journal 9(3): 26-41. http://dx.doi.org/10.1111/j.1748-8583.1999.tb00201.x

Rigby, M. 2002. Spanish trade unions and the provision of continuous training: partnership at a distance, Employee Relations 24(5): 500-515. http://dx.doi.org/10.1108/01425450210443276

Santos-Vijande, M.; López-Sánchez, J.; Trespalacios, J. 2012. How organizational learning affects a firm's flexibility, competitive strategy, and performance, Journal of Business Research 65(8): 1079-1089. http://dx.doi.org/10.1016/j.jbusres.2011.09.002

Streb, C.; Voelpel, S.; Leibold, M. 2008. Managing the aging workforce: status quo and implications for the advancement of theory and practice, European Management Journal 26(1): 1-10. http://dx.doi.org/10.1016/j.emj.2007.08.004

Tracey, J. 2012. A contextual, flexibility-based model of the HR-firm performance relationship, Management Decision 50(5): 909-924. http://dx.doi.org/10.1108/00251741211227609

Tripartite Foundation (Fundación Tripartita para la Formación en el Empleo). 2012. Observatorio y Estadísticas [online], [cited 30 September 2012]. Available from Internet: http://www.fundaciontripartita.org/index.asp? $\mathrm{MP}=6 \& \mathrm{MS}=24 \& \mathrm{MN}=1 \& \mathrm{r}=1317 * 823$

Veum, J. 1995. Sources of training and their impact on wages, Industrial and Labour Relations Review 48(4): 812-826. http://dx.doi.org/10.1177/001979399504800413

Guillermo O. PÉREZ-BUSTAMANTE ILANDER holds a PhD and is a Lecturer of Business Organization at the University of Oviedo, Spain. Currently, he is the Director of Graduate Employability at the same university. He has been teaching Technology Management at the Business School since 1994. His research interests include technology and knowledge management and entrepreneurship. He has lectured as Visiting Professor in France, Portugal, Colombia, Argentina and Peru, as well as in several Spanish universities.

Carla S. E. MARQUES is an Assistant Professor of Management at the Department of Economics, Sociology and Management, University of Trás-os-Montes e Alto Douro (UTAD), Vila Real, Portugal. In her PhD in Management Science (UTAD), she evaluated Portuguese industrial firms' innovation strategies. She is the Coordinator of the 'Innovation, Markets and Organization' research group at UTAD's Centre for Transdisciplinary Development Studies (CETRAD). Her research on innovation and entrepreneurship has been presented at numerous international conferences and published in international journals such as Service Business, Journal of Business Research, International Journal of 
Management and Enterprise Development, International Entrepreneurship and Management Journal, and Management Research. She is a regular reviewer for the Ibero-American Academy of Management, USASBE Meeting, European Journal of Innovation Management, and International Journal of Management and Information Technology. Her research interests include innovation, management of change and entrepreneurship.

Marjan S. JALALI is Assistant Professor at the ISCTE Business School of the University Institute of Lisbon, and researcher at the Business Research Center (BRU-IUL), Portugal. She holds a PhD in Management from the University of Sydney, Australia. She is editorial board member of the Global Business and Economics Review, managing editor of the International Journal of Management Science and Information Technology, and some of her works have been published nationally and internationally. Her research interests include multiple criteria decision analysis, strategic decision making and consumer behavior.

Fernando A. F. FERREIRA is Assistant Professor at the ISCTE Business School of the University Institute of Lisbon, and Adjunct Research Professor at the Fogelman College of Business and Economics of the University of Memphis, TN, USA. He holds a PhD in Quantitative Methods Applied to Economics and Management from the University of Algarve, Portugal. He is Section Editor of the Global Business and Economics Review and Editorial Board Member of several international journals. Some of his articles are published by ISI-listed journals such as Journal of the Operational Research Society, Management Decision, International Entrepreneurship and Management Journal, and International Journal of Strategic Property Management. He has practical experience as group facilitator and his research interests include multiple criteria decision analysis and integrated systems for performance measurement. 